\title{
MEMBINCANG GERAKAN ISLAM TRANSNASIONAL
}

\author{
Eko Kurniawan Wibowo
}

\begin{abstract}
Abstraksi
Sejatinya Islam merupakan agama yang bersifat transnasional. Pemahaman akan sifat transnasional ini berdasarkan sifat dari agama Islam yang bersifat missioner. Hasrat untuk menobatkan orang-orang di luar Islam merupakan kewajiban bagi umat Islam atau yang disebut dengan dakwah. Persoalan muncul ketika gerakan Islam transnasional berubah dan dipahami sebagai gerakan politik untuk menyatukan umat Islam dalam satu teritori atau satu negara. Kesatuan umat Islam di bawah payung satu negara atau disebut khilafah islamiyyah menjadi ambisi gerakan Islam transnasional. Cita-cita mendirikan kembali khilafah Islamiyah tersebut merupakan cara mengembalikan kejayaan Islam yang saat ini sedang tertindas oleh Barat.
\end{abstract}

Key words: Gerakan, Islam Transnasional, khilafah Islamiyyah, Barat.

\begin{abstract}
Indeed Islam is a transnational religion. This understanding of transnational nature is based on the nature of a missionary Islam. The desire to convert people outside of Islam is a duty to Muslims or so called $d a^{\prime} w a$. Problems arise when the transnational Islamic movement changes and is understood as a political movement to unite Muslims in one territory or one country. The unity of Muslims under the umbrella of one country or called the islamiyya caliphate becomes the ambition of the transnational Islamic movement. The goal of re-establishing the Islamic Caliphate was a way to restore the glory of Islam which is currently being oppressed by the West.
\end{abstract}

Keywords: Movement, Transnational Islam, Islamic Caliphate, West.

\section{Mukadimah}

Istilah transnasional semula dipergunakan untuk menunjuk pada aktivitas imigrasi dan diaspora ${ }^{1}$, dimana aktivitas itu hanya ditujukan pada perpindahan penduduk antar negara. Definisi tersebut kemudian bergeser dan menjadi meluas, yaitu "multiple ties and interactions linking people or institutions across the borders of modern nation-states"2. Jadi relasi antara manusia ataupun organisasi yang melintasi batas negara merupakan bagian dari aktivitas transnasional. Pengaruh dari teknologi yang berkembang dengan pesat saat ini semakin memudahkan aktifitas dan pergerakan transnasional. Pemahaman gerakan transnasional dalam perkembangannya selanjutnya bergeser men-jadi

${ }^{1}$ Delmus Puneri Salim, The Transnational and the Local in The Politics of Islam: The Case of West Sumatra Indonesia, (Swiss: Springer 2015) h.9 . Lih. juga Ihzan Yilmaz, "Transnational Islam", gerakan lintas batas negara dan bangsa yang berusaha menghadirkan atau menyebarkan ideologi tertentu.

Menurut pemahaman tersebut, pada dasarnya semua agama-agama Wahyu bersifat transnasional. Sifat transnasional dalam setiap agama Wahyu terkait dengan hasrat untuk mewartakan atau menyebarkan ke-benaran yang diterima dari Ilahi. Hasrat untuk mewartakan tersebut merupakan tugas atau amanat ilahi yang dianggap sebagai kewajiban bagi para pemeluknya. Agama Kristen misalnya, yang mempunyai mandat untuk melakukan misi menyebarkan atau mewartakan Injil, pada dasarnya juga melakukan relasi transnasional. Tersebarnya agama Kristen hampir di seluruh belahan dunia merupakan bukti bahwa agama Kristen me-rupakan

European Journal of Economic and Political Studies, 2010, h.1.

${ }^{2}$ Ihzan Yilmaz, "Transnational Islam", h.1. 
agama yang bersifat trans-nasional. Begitu pula Islam, juga me-rupakan agama wahyu yang bersifat transnasional. Pewartaan akan wahyu yang diterima oleh nabi Muhammad SAW merupakan tugas dari para umat Muslim. Hal tersebut bisa dilihat bagaimana ekspansi Islam dalam menyebarkan ajaran Islam keluar dari tanah Arab. Sentuhan transnasional juga bisa dilihat dari rukun Islam yang kelima, yaitu melakukan ibadah Haji. Ibadah Haji, selain kewajiban bagi umat Islam - bagi yang mampu - juga menjadi salah satu faktor penyebaran ideologi sampai terjadinya purifikasi dan revivalisme Islam di Indonesia. Pada jaman kolonialisme ada beberapa warga Hindia Belanda (Indonesia) yang melakukan per-jalanan berhaji dan juga menuntut ilmu di Arab Saudi. Beberapa yang kembali ke Indonesia membawa pemahaman yang bahwa Islam yang dipahami oleh orang-orang di Indonesia belum atau bahkan bersifat menyimpang atau keliru. Purifikasi yang dibawa pada masa itu ada yang bersifat sangat radikal-fundamentalis. Sikap dan pemahaman tersebut cukup ekstrim, hal tersebut bisa terjadi karena bersentuhan atau mendapatkan pengaruh yang kuat dengan aliran Wahabi di Arab Saudi yang baru berkembang dengan pesat. $^{3}$ Sampai hari ini aliran wahabi atau wahabisme merupakan aliran yang saat ini berkuasa di Arab Saudi. Gerakan-gerakan Islam trasnasional sudah mulai terjadi sejak lama serta me-miliki makna yang berbeda dan terus akan bergeser.

\section{Wajah Gerakan Islam Trans-nasional}

Istilah Islam transnasional sendiri saat ini maknanya sudah mulai bergeser dan dikaitkan dengan gerakan Islam mondial yang hendak memberlakukan syariat Islam

\footnotetext{
${ }^{3}$ Ayumardi Azra, Jaringan Ulama: Timur Tengah dan Kepulauan Nusantara Abad XVII dan XVIII (Akar Pembaruan Islam Indonesia), (Bandung: Mizan, 2004), hlm. 1-19

${ }^{4}$ Khurshid Ahmad, Pendahuluan, dalam Abul A'la Al-Maududi, Hukum dan Konstitusi
}

dan mendirikan negara Islam di berbagai negara, khususnya negara-negara yang penduduknya mayoritas Muslim. Saat ini sedang marak gerakan-gerakan untuk menegakkan syariat Islam dan pembentukan negara Islam, seperti di Sudan, Pakistan, Malaysia dan juga Indonesia. Gerakan tersebut di dalam rangka memberi kerangka konstitusi Islam dan pengenalan hukum Islam ${ }^{4}$. Maraknya gerakan tersebut di berbagai negara belahan dunia tidak lepas dari gerakan Islam transnasional dengan jargon Islam kaffah atau secara harafiah Islam yang sempurna atau secara lengkap. Semangat Islam-isme merupakan semangat yang diusung gerakan tersebut. Islamisme sendiri merupakan istilah yang saat ini ditujukan untuk menunjuk kepada gerakan Islam sebagai ideologi politis.

Membincang gerakan Islam Transnasional, tidak bisa dilepaskan dari hasrat untuk memperkenalkan Islam yang benar, Islam yang menye-luruh, Islam yang tidak memisahkan antara agama dan negara, Islam yang benar-benar mengacu pada al-Quran dan Sunnah Rasul. Penegakkan Islam Syariat tersebut bersifat gerakan ideologis keagamaan yang berupaya menghadirkan ajaran Islam dalam setiap aspek kehidupan dan menyatu-kan umat Islam dalam satu komunitas (ummah). ${ }^{5}$ Pemahaman gerakan penyatuan umat Islam dalam satu wadah tersebut, dipahami secara berbeda oleh beberapa kelompok. Per-bedaan tersebut didasarkan pada pemahman mengenai hubungan Islam dan Negara. Munawir Sjadzali membaginya menjadi tiga ${ }^{6}$. Kelompok pertama, paham ini melihat bahwa agama Islam bukan seperti agama yang dipahami oleh Barat, yang memahami bahwa agama sebatas hubungan manusia dengan Tuhan. Aliran ini memahami bahwa islam adalah

Sistem Politik Islam, terjemahan (Bandung: Mizan, 1995), h. 30.

5'Ihzan Yilmaz, "Transnational Islam”, h.2.

${ }^{6}$ Munawir Sadzali, Islam dan Tata Negara: Ajaran, Sejarah, dan Pemikiran (Jakarta: UI-Press, 1993), h. 1. 
agama yang lengkap, yang mengatur segala aspek kehidupan, bahkan tentang sistem negara dan politik. Teladan dari sistem negara dan politik Islam adalah dari nabi Muhammad dan al-Khulafaur al-Rasyidin (empat sahabat Nabi yang menjadi pemimpin atau khalifah). Karenanya, Islam tidak perlu meniru sistem negara dan politik Barat karena Muhammad sudah memberi teladan yang sempurna. Tokoh-tokoh aliran ini seperti Hasan al-Bana, Sayyid Qutbh, Rasyid Rida, Maulana Maududi dan Taqiyudin Nabhani. Kelompok Islam yang masuk dalam pemahaman ini seperti, Ikhwanul Muslimin, Hizbut Tahrir, serta ISIS. Kedua, kelompok ini memahami bahwa Islam adalah agama yang juga dipahami oleh Barat. Islam yang dibawa oleh Muhamamad, tidak pernah bertujuan mendirikan negara. Tokoh-tokoh pemikir gerakan ini adalah Thaha Husain dan Ali Abdul Al-Raziq. Pemahaman ketiga, kelom-pok ini menolak pemahaman kelompok pertama dan kelompok kedua. Aliran ini memahami bahwa dalam Islam tidak terdapat sistem ketata-negaraan, tetapi terdapat tata nilai etika kehidupan bernegara. Pemikir dari kelompok ini adalah Muhammad Husein Haikal. Pemahaman kelompok ketiga ini bisa dilihat dalam pemikiran Nurkholis Madjid (Cak Nur) dan Gus Dur dengan konsep masyarakat madani.

Pergerakan penyatuan agama dan negara atau Islam politik tersebut saat ini dilekatkan pada Gerakan Islam Transnasional yang bersifat funda-mentalis Islam $^{7}$, seperti Ikwanul Muslimin, Hizbut Tahrir, dan Jemaah Islamiyah ${ }^{8}$. Gerakan fundamentalis Islam saat ini lebih dimaknai secara negatif, yaitu gerakan yang bersifat ekstrim dan keras. Begitu pula kelompok

${ }^{7} \mathrm{M}$ Zaki Mubarak, Genealogi Islam Radikal di Indonesia: Gerakan, Pemikiran dan Prospek Demokrasi, (Jakarta: Pustaka LP3ES, 2007), h. 110

${ }^{8}$ Kees de Jong, "A Survey of Recent Developments in Indonesia: The Radicali-sation of Religions during the Reformation Period", Studies Interreligious Dialogue, 22/2012/1, h. fundamentalis Islam dikaitkan dengan penindasan terhadap perempuan, kekejaman hukuman atas pelanggaran terhadap norma agama, fanatik terhadap keyakinan, memusuhi Barat, serta kecenderungan terhadap kekerasan bahkan terorisme. ${ }^{9}$ Feno-mena terbaru yang saat ini bisa kita cermati adalah kemunculan ISIS (Islamic State of Irak and Syam). ISIS merupakan gerakan Islam yang sangat radikal. Cita-cita dari ISIS adalah menyatukan Islam ke dalam satu negara Islam mondial (khilafah). Perjuangan ISIS tersebut mengguna-kan berbagai macam cara, termasuk melakukan pembunuhan dan kekeras-an. Kemunculan ISIS dengan ambisi untuk mewujudkan kembali khilafah islamiyah mendapat respon yang beragam dari kalangan umat Islam. Banyak orang ataupun kelompok Islam yang dengan tegas menolak ISIS, walau begitu ada juga yang mendukung apa yang dilakukan oleh ISIS. Seperti yang telah dipaparkan sedikit di atas bahwa Islamisme atau Islam politik saat ini telah menjelma menjadi gerakan transnasional yang mempunyai berbagai bentuk dan cara untuk memperjuangkan penegakan negara Islam baik yang bersifat lokal ataupun mondial. Baik negara Islam lokal ataupun mondial mempunyai kesamaan nilai, yaitu menghadirkan wajah Islam yang sempurna dalam setiap aspek kehidupan atau, dengan memakai bahasa dari Haedar Nashir, menegakkan Islam Syariat ${ }^{10}$.

\section{Pola Gerakan Islam Transnasional}

Wujud gerakan Islam trans-nasional tersebut saat ini telah menjelma menjadi gerakan yang ingin menghadirkan wajah Islam yang "benar" kehidupan umat Muslim. Fenomena ini bisa

${ }^{9}$ Richard T Antoun, Memahami Fundamentalisme: Gerakan Islam, Kristen, Yahudi, terjemahan (Surabaya: Pustaka Euraka, 1999), h. 1

${ }^{10}$ Haedar Nashir, Islam Syariat: Reproduksi Salafiyah Ideologis di Indonesia, (Bandung dan Jakarta: Mizan dan Maarif Institute).

${ }^{11}$ Benar disini lebih menunjuk pada penafsiran tentang Islam pada kelompok 
dilihat dari berbagai macam pen-dekatan. Pendekatan integralistik me-lihat fenomena tersebut, merupakan respon dan perlawanan dari hegemoni Barat dengan konsep modernitas yang diusungnya. Modernitas yang dige-makan oleh barat tersebut juga sangat mempengaruhi pola pemikiran umat Muslim di dunia. Modernitas yang menghasilkan sekulerisme, liberalisme dan pluralisme oleh beberapa kalang-an, terutama kalangan integralistik, dianggap "racun" bagi umat Muslim. Di Indonesia sendiri gerakan integral-istik yang bersifat trans-nasional tersebut mempunyai dampak yang cukup kuat di kalangan para ulama. Ini bisa dilihat dari fatwa yang dikeluarkan oleh Majelis Ulama Indonesia (MUI) mengenai bahaya dan haramnya pemikiran tentang Sipilis (Sekulerisme, Pluralisme dan Liberalisme). ${ }^{12}$ Hal-hal tersebut dianggap produk modernitas yang merupakan hasil dari rasionalitas Barat, yang ingin menghancurkan Islam. Secara umum pola gerakan Islam transnasional itu bisa dibagai menjadi tiga bagian, berdasarkan aktifitas gerakan tersebut. Pola-pola dalam gerakan Islam transnasional di Indonesia, adalah sebagai berikut:

Pertama, Transmisi dan tranformasi pengetahuan. Secara umum Islam adalah agama yang bersifat transnasional atau bersifat universal. Hal tersebut disebabkan karena agama Islam adalah yang bersifat misioner $\left(d a^{\prime} w a\right)$. Sesuai dengan apa yang diyakini banyak umat Muslim, setiap Muslim mempunyai

fundamentalis yang cenderung literal dalam membaca dan menasirkan Quran dan Hadis.

${ }^{12}$ Hijrah Saputra dkk., (eds), Himpunan

Fatwa Majelis Ulama Indonesia Sejak 1975, (Jakarta: Erlangga, 2011), h. 87-95

${ }^{13}$ Kate Zebiri, Muslims and Christians Face to Face, (Oxford: OneWorld 1997), h.28-29.

${ }^{14}$ Ibid.

${ }^{15}$ Teori Arab adalah teori yang mengatakan bahwa agama Islam itu masuk di Nusantara dibawa oleh para pedagang dari Arab yang merupakan keturunan langsung dari Nabi Muhammad SAW , dimana penyebaran itu sudah dimulai pada abad ke 7. Lih Ayumardi Azra, Jaringan Ulama: Timur Tengah dan Kepulauan Nusantara Abad XVII dan XVIII (Akar Pembaruan Islam Indonesia), tanggung jawab untuk melakukan penyebaran agama Islam (berdakwah) ${ }^{13}$. Melihat kecen-derungan seperti itu, di awal mula penyebaran agama Islam, para penyebar umat Muslim melakukan berbagai cara untuk "mewartakan kabar suka-cita" tersebut. Melalui da'wa tersebut bertujuan untuk me-wujudkan satu komunitas Islam atau Umma ${ }^{14}$. Menu-rut "teori Arab"15 yang mengemuka-kan bahwa agama Islam masuk ke Indonesia melalui jaringan pedagang dari Arab yang membawa-nya masuk ke Indonesia. Teori kedatangan Islam yang hadir di Indonesia datang langsung dari Arab membuat transfer ilmu pengerahuan tentang Islam datangnya langsung dari tempat lahir-nya Islam. Jadi gerakan dakwah yang merupakan unsur inheren dari agama Islam membawa konsekuensi logis bahwa Islam merupakan agama yang bersifat transnasional (universal). Trans-formasi ilmu pengetahuan ke-agamaan Islam tersebut akan menjadi lebih sahih jikalau mempunyai keter-ikatan atau mempunyai benang merah dengan jaringan ulama yang ada di Timur Tengah. Keterikatan langsung dengan ulama Timur Tengah itu merupakan legitimasi $^{16}$ bahwa ilmu pengetahuan mereka adalah produk asli dari Arab sebagai sumber utama dari lahirnya Islam ${ }^{17}$. Transformasi Ilmu Pengetahuan tersebut tidak hanya yang bersifat substanstif saja tetapi mereka juga berusaha untuk mentrans-formasikan cara-cara hidup,

(Bandung: Mizan, 2004), hlm. 1-19. Lih juga Martin van Bruinessen, 2012.

${ }^{16}$ Persoalan legitimasi ini bisa dilihat jelas ketika terjadi konflik di Ambon. Panglima Laskar Jihad yaitu Jaf'ar Umar Thalib harus meminta rekomendasi dari para ulama di Arab Saudi untuk memberikan keabsahan jihad yang mereka lakukan di Ambon. Lih. Norhaidi Hasan, Laskar Jihad: Islam, Militansi, dan Pencarian Identitas di Indonesia Pasca-Orde Baru, (Jakarta: LP3ESKITLV, 2008), h.

${ }^{17}$ Ayumardi Azra, Jaringan Ulama: Timur Tengah dan Kepulauan Nusantara Abad XVII dan XVIII (Akar Pembaruan Islam Indonesia), (Bandung: Mizan, 2004), h.1-19. 
seperti cara berpakaian dalam kehidupan sehari-hari (kearab-araban).

Kedua, gerakan kesalehan (politic of piety), ${ }^{18}$ membaca dunia yang semakin sekuler beberapa ke-lompok Islam ingin merubah situasi tersebut, akan tetapi situasi tersebut tidak akan bisa dirubah secara terpisah, diperlukan kesatuan diantara Muslim dimanapun tempat yang mengatasi batasan budaya, etnis dan bahkan negara. Budaya barat yang semakin mewarnai berbagai bidang kehidupan di dunia membuat mereka ingin memberi warna yang islami, dimana warna islami tersebut diharap-kan merupakan tameng yang ampuh dalam menghadang westerin-isasi. Gerakan kesalehan tersebut mula-mula lebih bersifat individual, dimana kelompok ini beranggapan bahwa sistem yang sudah berlaku saat ini hanya bisa diatasi dengan bentuk kesalehan pribadi, dimana hal tersebut akan memperkokoh dan memperkuat pemahaman iman mereka ${ }^{19}$. Pola gerakan kesalehan pribadi tersebut juga dipakai kelompok-kelompok yang bersifat radikal-fundamentalis. Hadirnya kelompok-kelompok kecil atau sel seperti maraknya halaqah atau daurah ${ }^{20}$ di banyak tempat, merupakan upaya pengkaderan bagi para rekrutan kelompok tersebut supaya mempunyai ketaatan yang absolut terhadap agama dan kelom-poknya.

Ketiga, gerakan politik, pola gerakan transnasional tersebut akan berubah menjadi gerakan politik jilakau sudah mempunyai massa yang cukup untuk mauk dalam kancah politik nasional, seperti Ikwanul Muslimin yang bermetamorfosis men-jadi Partai Keadilan Sosial (sebelumnya adalah Partai Keadilan). Seperti yang jamak dipahami oleh berbagai

\footnotetext{
${ }^{18}$ Gerakan kesalehan di Indonesia ini bisa dilihat dari gerakan dzikir yang dipopulerkan oleh ustad Arifin Ilham. Gerakan doa dan dzikir tersebut saat ini telah berkembang kepada gerakan untuk mendukung gerakan-gerakan politik tertentu yang dibalut sebagai gerakan pemurnian Islam.

${ }^{19}$ Saba Mahmood, Politics of Piety, (Princeton: Princeton University Press, 2004), h.

${ }^{20}$ Halaqah adalah gerakan pengajaran oleh guru kepada murid-muridnya dalam jumlah kecil
}

kalangan, bahwa gerakan Islam transnasional seringkali di-pahami sebagai gerakan yang bersifat ideologis-politis yang mengusung misi tegaknya Daulah Islamiyyah (Negara Islam) baik yang bersifat lokal ataupun universal. Gerakan politik menegakkan berdirinya Daulah Islam-iyyah tersebut terjadi juga karena keprihatinan dari banyak kalangan Islam yang beranggapan bahwa proyek modernitas merupakan proyek yang ingin menanamkan nilai-nilai barat di seluruh dunia. Nilai nilai Barat (baca: Kristen) tersebut di-anggap salah satu upaya untuk menghilangkan Islam dari muka bumi ini. Proyek modernitas barat tersebut tentunya akan menghilangkan eksis-tensi agama Islam di atas muka bumi ini. Modernitas Barat sendiri telah mengalami kegagalan dan meng-hasilkan sistem atau tatanan dunia yang tidak memihak Islam. Walhasil pemahaman seperti itu menghasilkan gerakan politis yang ingin mengem-balikan posisi Islam sebagai agama yang hadir dalam setiap aspek kehidupan umat Muslim $\left(\right.$ Islam Kaffah) ${ }^{21}$. Gerakan-gerakan tersebut banyak yang lahir di daerah Timur Tengah, yang sebenarnya tidak terjadi secara kebetulan. Hal tersebut di-sebabkan Timur Tengah merupakan daerah yang menjadi salah satu sasaran dari pihak Barat untuk bisa dikuasai. Penguasaan daerah Timur tengah tersebut sebenarnya sangat bersifat ekonomis dan politis. Hasrat menguasai Timur Tengah berkaitan dengan sumbersumber minyak yang masih begitu melimpah di daerah tersebut. Untuk bisa mengatasi hegemoni Barat terhadap dunia Islam tersebut, sarana yang paling ampuh untuk terus diwacanakan adalah dengan menggunakan sentimen ke-agamaan, yang

(sel), sementara Daurah adalah workshop yang diadakan dalam waktu tertentu dalam waktu yang relatif agak lama. Lih. Noorhaidi Hasan, Laskar Jihad: Islam, Militansi, dan Pencarian Identitas di Indonesia Pasca-Orde Baru, (Jakarta: LP3ESKITLV, 2008), h.32.

${ }^{21}$ Haedar Nashir, Islam Syariat: Reproduksi Salafiyah Ideologis di Indonesia, (Bandung: Mizan dan Maarif Institute, 2012),h. 388. 
merupakan isu paling ampuh untuk membakar semangat membela agama. Sentimen agama ter-sebut dimunculkan dengan dalih memerangi kebatilan atau jahat yang merupakan musuh dari Islam. Gerakan politik yang lahir karena semangat untuk mengembalikan ajaran Islam secara menyeluruh (Kaffah) dalam kehidupan umat Muslim, melahirkan banyak gerakan yang satu dengan yang lainnya memiliki ide atau corak yang berbeda. Tetapi satu hal yang bisa menyatukan mereka adalah perasaan tertindas oleh Barat, yang dalam hal ini mereka sangat percaya bahwa Barat sedang berkonspirasi dengan Yahudi untuk menghancurkan dunia Islam. Kehancuran terebut me-numbuhkan semangat kebangkitan (Revivalisme) ${ }^{22}$ dalam diri beberapa pihak umat Muslim. Kebangkitan tersebut dimulai dengan cara merubah nalar berpikir dan cara hidup umat Islam $^{23}$. Revivalisme politik tersebut menurut Ibnu Taimiyyah disebut dengan "Muhyi atsari Salaf", yaitu menghadirkan cara hidup generasi pertama umat Islam (salaf). Generasi pertama adalah generasi Nabi Muhammad dan para sahabatnya yang mempraktekkan Islam secara saleh ${ }^{24}$. Citacita gerakan politis terebut secara umum adalah menciptakan satu komunitas Islam dunia (Ummah) yang dipimpin oleh seorang Khalifah (Khilafah Islamiyyah). Beberapa gerakan politis tersebut antara lain : Al-Ikhwan Al Muslimin (Persaudaraan Muslim atau Ikhwanul Muslimin), Jamaati-Islami, Taliban, dan Hizbut Tahrir (Partai Pembebasan $)^{25}$.

\section{Faktor-faktor Gerakan Islam Transnasional}

Kegelisahan umat Muslim kontemporer terhadap modernitas Barat yang mengancam eksistensi dari agama Islam tersebut menghasilkan gerakan

\footnotetext{
${ }^{22}$ Haedar Nashir, Islam Syariat: Reproduksi Salafiyah Ideologis di Indonesia, (Bandung: Mizan dan Maarif Institute, 201),h.184. Lih. Juga Abdul Qadim Zallum, Konspirasi Barat
}

transnasional politis. Sebelum jaman pra modern, gerakan politik di kalangan islamis lebih menekankan respon karena terjadinya masalah dalam tubuh penguasa. Aktor utama dari gerakan politis sendiri adalah ulama-ulama yang berada di luar pemerintah. Saat ini gerakan politis Islam identik dengan kontra terhadap modernitas. Namun demikian, tidak bisa dihindari bahwa pengaruh pe-mikiran modernitas sendiri telah berkelindan dalam gerakan Islam poli-tis kontemporer. Di satu sisi modern-itas merupakan ancaman tetapi di sisi lain moderitas yang terjadi justru merupakan faktor yang sangat berpengaruh di dalam munculnya per-gerakan politis mondial Islam. Faktor-faktor tersebut juga tidak lepas dari eskalasi politik global yang terjadi. Faktor-faktor tersebut adalah:

\section{Kondisi Geopolitik Pada Masa Akhir Kolianialisme}

Perang Dunia I dan Perang Dunia II mengakibatkan semangat untuk membela tanah airnya yang diserang oleh bangsa lain. Semangat untuk berjuang membela dan mem-pertahankan harga diri bangsa dan negara itulah yang disebut dengan Nasionalisme. Semangat Nasional-isme yang tumbuh pada paruh pertama abad ke 20 juga ternyata menjadi virus ampuh yang juga menjalar di negara-negara Islam Timur Tengah Perasaan sebagai satu bangsa Negara (nation State) tersebut mulai menghilangkan semangat persatuan Islam (Ukhuwah Islamiya), dimana semangat ini dipahami sebagai umat Islam satu yang melampui batas Suku, Negara dan bangsa. Tumbuhnya semangat nasionalisme tersebut dianggap se-bagai suatu ancaman akan eksistensi dari persatuan umat Muslim. Na-sionalisme dipahami suatu paham yang lebih mementingkan bangsa dan tanah air. Kesetiaan kepada negaranya

meruntuhkan Khilafah Islamiyah, (Bangil: Al-Izzah, 2001), h.1-12.

${ }^{23}$ Ibid.

${ }^{24}$ Ibid. hlm 185

${ }^{25}$ Ibid. 
dianggap lebih penting daripada dengan saudara yang seaqidah ${ }^{26}$. Ajaran nasionalisme tersebut tidak sesuai dengan ajaran Islam,ketaatan seorang Muslim yang paling utama adalah taat kepada Allah $\mathrm{SWT}^{27}$. Gerakan Nasioanalisme yang dianggap oleh banyak kalangan Islam sebagai cara ampuh Barat dalam menghancurkan kekhalifahan Islam $^{28}$. Keyakinan tersebut semakin menguat dengan keruntuhan kekhilafahan Utsmani di Turki ${ }^{29}$ dan lahirnya Negara Bangsa (Nation State) yang merupakan imbas dari bangkitnya semangat Nasionalisme. PD I dilanjutakan dengan PD II serta keruntuhan dari Turki Utsmani pada tahun 1924 merupakan konstelasi geopolitik abad 19 akhir dan memasuki awal abad 20 yang melahirkan nasionalisme serta me-lahirkan negaranegara modern baik di dataran Eropa dan Timur Tengah.

\section{Perang Arab Israel, Zionisme dan Isu kemerdekaan Palestina}

Berdirinya Negara Israel modern pada tahun 1948 membuat eskalasi geopolitik di kalangan umat Islam semakin memanas, sehingga mengakibatkan terjadinya konfrontasi senjata. Palestina yang merupakan tempat suci kedua setelah Mekah dianggap sebagai tempat yang harus dikuasai oleh kalangan Islam (Arab). Pengguasaan tanah Palestina oleh bangsa Yahudi dianggap sesuatu yang bertentangan dengan kehendak dari Tuhan. Hal tersebut yang mengakibat-kan permusuhan Arab-Israel terus memanas. Sementara klaim dari pihak Yahudi sendiri yang merasa bahwa tanah Palestina adalah tanah Per-janjian yang diklaim sebagai tanah yang diberikan oleh Allah sendiri, dan wajib dipertahankan. Ketegangan yang

\footnotetext{
${ }^{26}$ Ibid. hlm 9

${ }^{27}$ Ismail Yusanto, Islam Ideologi: Refleksi Cendikiawan Muda, (Bangil: Al-Izzah, 1998), h.7.

${ }^{28}$ Abdul Qadim Zallum, Konspirasi Barat meruntuhkan Khilafa Islamiyah, (Bangil: Al-Izzah, 2001), h.13-28.

${ }^{29}$ Ibid
}

mengatas namakan Tuhan se-bagai sumber otoritas truth claim mereka, membuat konflik Arab-Israel terus berlangsung sampai hari ini.

\section{Kapitalisme Global}

Dunia saat ini dicengkeraman oleh kapitalisme global yang me-nguasai hampir setiap aspek kehidupan baik sosial, politik, eko-nomi, budaya dan militerisme. Setelah berakhirnya Perang Dunia ke II, Amerika Serikat dan sekutunya terus mencoba menguasai dunia dengan program Developmentisme. Develop-mentisme adalah semacam program pembangunan bagi negara-negara yang sedang berkembang atau di negara dunia ketiga seperti yang terjadi di era Suharto (Orde Baru). Dari istilah terebut saja sudah menggambarkan istilah yang inferior terhadap negara-negara maju. Dalam hal ini negara maju diidentikkan dengan negaranegara Barat.

Setidaknya tiga hal yang telah disebutkan diatas mematik terjadinya Gerakan Islam transnasional, yang lebih mengarah atau mempunyai cita-cita menyatukan umat Islam dimanapun tempat untuk melawan hegemoni Barat yang sudah begitu mencengkeram dunia. Islam harus bangkit dan melawan setiap aspek hegemoni Barat yang dianggap sebagai sumber setiap masalah yang ada dalam dunia $^{30}$. Gerakan Islam Transnasional tersebut menyerukan bahwa masalahmasalah yang terjadi saat ini hanya bisa dikembalikan kepada Islam, sebagai jawaban dari permasalahan yang terjadi. Kelompok-kelompok transnasional yang juga hadir di Indonesia adalah Hizbut

\footnotetext{
${ }^{30}$ Alwi Shihab, "Membangun Jem-batan Melaui Dialog Antaragama", dalam Mengelola Keberagaman di Indonesia: Agama dan Isu-Isu Globalisasi, Kekerasan, Gender, dan Bencana di Indonesia,Ed. Bernard Adeney Risakotta, (Yogyakarta-Bandung: ICRS dan Mizan 2015), hlm. 170 .
} 
Tahrir atau Partai Pembebasan (di Indonesia disebut HTI atau Hizbur Tahrir Indonesia), Ikhwanul Muslim yang menjelma menjadi PKS (Partai Keadilan Sosial). Kemudian kelom-pok-kelompok separatis seperti Laskar Jihad dan Majelis Mujahidin Indo-nesia (MMI. Kelompokkelompok tersebut merupakan salah satu organ-isasi politik Islam transnasional. Oleh beberapa pihak, organisasi atau kelompok tersebut disebut sebagai organisasi yang bersifat Radikalis-Fundamentalis.

Pergerakan Islam Trans-nasional yang disematkan kepada kelompokkelompok radikal funda-mentalis tersebut mempunyai ciri-ciri, sebagai berikut.Pertama, penegakan Syariat Islam dalam politik ketata-negaraan, dimana ini berbeda dengan pengamalan syariat Islam dalam kehidupan sehari-hari. Penegakan ini bersifat bersifat formal legalitas, yang berarti Syariat Islam adalah menjadi dasar atau hukum dalam kehidupan bersama. Kedua, kepemimpinan glo-bal atau yang lebih populer dengan sebutan khilafah. Dua agenda besar terus didengungkan untuk mengatasi masalah-masalah yang ada yang semakin menghimpit kehidupan umat.

Dari analisa baik pola, relasi dan ciri-ciri gerakan Islam Trans-nasional seperti yang telah diuraikan diatas menyiratkan bahwa gerakan ini memperjuangkan ideologi politis kelompok mereka yang dirasa tepat diterapkan dalam konteks Global. Gerakan transnasional ini bersifat ideologis-agamis, maka yang diper-juangkan adalah gerakan yang bersumber dari pemahaman tentang Kitab Suci dalam hal ini sumbernya adalah al-Quran dan Hadits. Kebenar-an absolut yang diperjuangkan ter-sebut mempuyai dasar kebenaran dari Tuhan (truth claim) yang harus diperjuangkan. Truth claim

\footnotetext{
${ }^{31}$ Zuly Qodir, Syariah Demokratik: Pemberlakuan Syariah Islam di Indonesia, (Yogyakarta: Pustaka Pelajar 2004), h. 42.

${ }^{32}$ Reform Review, "Jurnal Untuk Kajian dan Pemetaan Krisis”, Vol I. No. I, April-Juni 2007, h.63.
}

yang di-gelorakan tersebut menolak pemahaman atau ideologi lokal yang telah berkembang dan telah diwujudkan ${ }^{31}$, seperti nation-state dan demokrasi Pancasila. Gerakan transnasional ter-sebut secara normatif mempunyai ciri-ciri, yaitu $^{32}$ : Pertama, semua gerakan bersifat transnasional, lintas bangsa, dan lintasnegara. Mereka mengem-bangkan jaringan gerakan dengan menciptakan sejumlah titik di berbagai negara, termasuk di negaranegara sekuler dan maju. Seperti HTI, mempunyai berbagai cabang di berbagai negara baik negara Eropa, Asia, Afrika dan juga Australia. Kedua, ideologi gerakan ini tidak lagi bertumpu pada konsep nationstate, negara yang berbasis bangsa, melainkan konsep kesejahteraan umat di tingkat global. Kesatuan atau per-wujudan umat secara utuh adalah tujuan yang hendak dikejar. Per-wujudan bangsa dan negara me-rupakan bagian dari proyek modern-itas untuk menghancurkan sistem khilafah yang sudah terbangun dengan baik. Menurut Iqbal Ahnaf, ke-lompokkelompok transnasional ini memiliki gerakan politik yang ekstrim seperti $A l$ Qaedah dan Jamaah Islamiya. ${ }^{33}$ Jadi secara normatif ke-lompok tersebut hanya menerima penerapan sistem politik Islam (Siyasah Islamiyah) atau negara Islam $\left(\right.$ Daulah Islamiyah) ${ }^{34}$. Ketiga, secara parsial mereka mengadaptasi gagasan dan instrumen modern seperti metode perjuangan politik, partai, hingga penggunaan teknologi informasi. Ini bisa dilihat bagaimana kelompok transnasional dalam menyebarkan wacana, ide dan dakwah mereka menggunakan berbagai media sosial modern yang ada, seperti web site, facebook, twitter, instagram dan

\footnotetext{
${ }^{33}$ Mohammad Iqbal Ahnaf, Memahami Radikalisme dalam Islam di Indonesia: Perspektif Kontruktivis, (Yogya-karta: CRCS, tidak diterbitkan) disampaikan dalam Studi Intensif Tentang Islam Tahun 2014 di GHCC Duta Wacana Jl kaliurang Km 23 Yogyakarta, hlm. 3 ${ }^{34}$ Ibid.
} 
youtube. ${ }^{35}$ Penggunaan dan adaptasi dengan instrument modern sebenarnya secara ideologis bertentangan dengan semangat gerakan transnasional Islam yang mengharamkan kemajuan atau ide yang dihasilkan Barat.

\section{Penutup}

Gerakan Islam transnasional merupa-kan kenyataan yang telah ada sejak Islam lahir di Jazirah Arab. Sebagai agama yang mengklaim sebagai agama penutup dan yang menyempur-nakan agama-agama sebelumnya, tidak bisa dipungkiri hasrat untuk mewartakan kebenaran menjadi misi utama mereka. Misi atau yang disebut dakwah tersebut menjadikan agama Islam sebagai agama yang bersifat transnasional. Pemahaman akan sifat-nya yang transnasional tersebut berimbas pada hasrat untuk menya-tukan umat Islam dalam satu paying besar yang disebut Negara. Hasrat menyatukan umat tersebut merupakan impian yang didasarkan pada kejayaan Islam di masa lalu khususnya di masa kekhalifahan yang pernah menguasai daerah-daerah di Eropa. Romantisme tersebut menjadi salah satu pemicu untuk menyatukan umat Islam yang saat ini dianggap mengalami kemun-duran dan penindasan dari Barat. Merunut apa yang telah dituliskan di atas, gerakan Islam transnasional saat ini telah menjelma menjadi gerakan politik yang didasari pada teks-teks suci agama Islam, romantisme kejayaan masa lalu serta perasaan tertindas yang dialami oleh umat Muslim di berbagai belahan dunia.

\section{BIBLIOGRAFI}

Ahmad, Khurshid. "Pendahuluan", dalam Abul A'la Al-Maududi, Hukum dan Konstitusi Sistem Politik Islam, terjemahan, Bandung: Mizan, 1995.

Ahnaf, Mohammad Iqbal. Memahami Radikalisme dalam Islam di
Indonesia: Perspektif Kontruktivis, (Yogyakarta: CRCS, tidak diterbitkan) disampaikan dalam Studi Intensif Tentang Islam Tahun 2014 di GHCC Duta Wacana Jl kaliurang Km 23 Yogyakarta.

Antoun, Richard $\mathrm{T}$. Memahami Fundamentalisme: Gerakan Islam, Kristen, Yahudi, Sura-baya: Pustaka Euraka, 1999.

Azra, Ayumardi. Jaringan Ulama: Timur Tengah dan Kepulauan Nusantara Abad XVII dan XVIII (Akar Pembaruan Islam Indonesia), Bandung: Mizan, 2001.

de Jong, Kees "A Survey of Recent Developments in Indonesia: The Radicalisation of Religions during the Reformation Period", in Studies Inter-religious Dialogue, 22/2012/1.

Hasan, Norhaidi. Laskar Jihad: Islam, Militansi, dan Pencarian Identitas di Indonesia Pasca-Orde Baru, Jakarta: LP3ES-KITLV, 2008.

Mahmood, Saba. Politics of Piety, Princeton: Princeton University Press, 2004.

Mubarak, M Zaki. Genealogi Islam Radikal di Indonesia: Gerakan, Pemikiran dan Prospek Demokrasi, Jakarta: Pustaka LP3ES, 2007.

Nashir, Haedar. Islam Syariat: Reproduksi Salafiyah Ideologis di Indonesia, Bandung dan Jakarta: Mizan dan Maarif Institute, 2012.

Qodir, Zuly. Syariah Demokratik: Pemberlakuan Syariah Islam di Indonesia, Yogyakarta: Pustaka Pelajar 2004.

Reform Review, "Jurnal Untuk Kajian dan Pemetaan Krisis", Vol I. No. I, April-Juni 2007.

Sadzali, Munawir. Islam dan Tata Negara: Ajaran, Sejarah, dan Pemikiran, Jakarta: UI-Press, 1993.

Salim, Delmus Puneri . The Transnational and the Local in The Politics of

\footnotetext{
${ }^{35}$ https://hizbut-tahrir.or.id/
} 
Islam: The Case of West Sumatra Indonesia, Swiss: Springer, 2015

Saputra, Hijrah. dkk., (eds), Himpunan Fatwa Majelis Ulama Indonesia Sejak 1975, Jakarta: Erlangga, 2011.

Shihab, Alwi. "Membangun Jembatan Melaui Dialog Antaragama”, dalam Mengelola Keberagaman di Indonesia: Agama dan Isu-Isu Globalisasi, Kekerasan, Gender, dan Bencana di Indonesia, Bernard Adeney Risakotta (ed), YogyakartaBandung: ICRS dan Mizan 2015

Yilmaz, Ihzan. "Transnational Islam", in European Journal of Econo-mic and Political Studies, 2010.

Yusanto, Ismail. Islam Ideologi: Re-fleksi Cendikiawan Muda, Bangil: AlIzzah, 1998.

Zallum, Abdul Qadim. Konspirasi Barat meruntuhkan Khilafah Islamiyah, Bangil: Al-Izzah, 2001.

Zebiri, Kate. Muslims and Christians Face to Face, Oxford: OneWorld, 1997.
Website:

https://hizbut-tahrir.or.id

\section{BIO DATA}

$\mathrm{Pb}$. Pdt. Eko Kurniawan Wibowo, S.Pd.K, M.Si.Teol., lahir 19 April !977 di Jepara. Dibesarkan dan menempuh pendidikan awal di Jepara. Pada tahun 2010 menyelesaikan pendidikan S1 di Sekolah Tinggai Agama Kristen (STAKWW) Pati. Kemudian tahun 2017 menyelesaikan pendidikan S2 Ilmu Teologi di PPST UKDW Yogyakarta. Mulai tahun 2013 sampai saat ini melayani di Gereja GITJ Jepara Pepanthan Yogyakarta. Selain aktif melayani di Gereja juga mengajar di Sekolah Tinggi Teologia Sriwijaya Palembang. Selain itu juga aktif dalam forum-forum dialog interreligius serta aktif dalam berbagai kegiatan membangun perdamaian lintas agama. 